\title{
Sex Differences in the Chronology of Deciduous Tooth Emergence in White and Black Children
}

\author{
PETER F. INFANTE \\ Center for Human Growth and Development, University of Michigan, \\ Ann Arbor, Michigan 48104, USA
}

Tooth emergence in 376 black and white children between the ages of 4 and 33 months was studied in southeastern Michigan. The results indicate a trend in both groups for boys to show earlier tooth emergence in early stages and for girls to show earlier tooth emergence in later stages of deciduous tooth emergence.

Numerous investigators have reported sex differences to be slight and irregular in the timing of deciduous tooth emergence. ${ }^{-4}$ From an extensive review of the literature, however, Meredith ${ }^{5}$ has concluded that boys are slightly advanced at all ages. Other investigators 6 have reported boys to have an earlier emergence of all deciduous teeth, with the exception of the first molars. Doring and Allen 7 reported boys to be significantly advanced in maxillary incisor emergence only. Ferguson, Scott, and Bawkin ${ }^{8}$ observed that both black and white boys had more teeth present at age one year than did their female counterparts. Others ${ }^{9}$ have shown boys to be advanced in incisor emergence, but girls to be advanced in all other teeth with the exception of the maxillary second molars.

In view of these contradictory findings based on various methods of data collection for children of diverse socioeconomic backgrounds, a further investigation seemed necessary. In the study reported here, there were 376 children from the same lower socioeconomic level who represented two racial groups.

\section{Materials and Methods}

The study was conducted at the Ypsilanti

This study was supported by Oral Epidemiology Training Grant No. 5T01-DE-00287-05 from the Na. tional Institutes of Health.

Received for publication March 15, 1973.
(Michigan) Well Baby Clinic, which functions primarily as a follow-up health evaluation and immunization clinic for preschool children of the lower socioeconomic levels. All children between the ages of 4 and 33 months who attended the clinic between April 1 and August 1, 1972, were examined. A tooth was considered emerged if any portion had pierced the oral mucosa. The child's birth date was obtained from the mother.

Means and standard deviations for the total number of deciduous teeth present were computed separately for each sex-race group by half-year age intervals (Table 1). The variation of the number of teeth present at each interval shows an abnormal distribution. For this reason, data were analyzed by medians as well as by means. Thus, a median tooth emergence trend line was established for boys of both races. Girls of each race were assessed as above or below the boys' trend line for the total number of teeth present by age. Comparisons then were made for the early stages of tooth emergence ( 6 to 15 months) and for the later stages of tooth emergence (greater than 15 months to 27 months for black children and to 29 months for white children). Because black children completed their deciduous dentition at earlier ages than did white children, their upper age interval was shorter.

Since about equal numbers of boys were above and below their tooth emergence trend lines in both the early and late stages of tooth emergence, a similar finding would have been expected for girls if no differences existed. Table 2 shows the comparisons for race groups separately and combined.

\section{Results}

The means for the total number of teeth 
TABLE 1

Mean Total Number of Deciduous Teeth in White and Black Children BY Half-Year Age INTERvals

\begin{tabular}{|c|c|c|c|c|c|c|c|c|}
\hline $\begin{array}{c}\text { Age } \\
\text { (months) }\end{array}$ & $\mathbf{N}$ & $\begin{array}{c}\text { Mean Age } \\
\text { (months) }\end{array}$ & $\begin{array}{l}\text { Mean No. } \\
\text { of Teeth }\end{array}$ & $\mathrm{SD*}$ & $\mathbf{N}$ & $\begin{array}{c}\text { Mean Age } \\
\text { (months) }\end{array}$ & $\begin{array}{l}\text { Mean No. } \\
\text { of Teeth }\end{array}$ & SD \\
\hline & \multicolumn{4}{|c|}{ White Boys } & \multicolumn{4}{|c|}{ White Girls } \\
\hline 3.00 to 8.99 & 26 & 6.63 & 1.92 & 2.50 & 36 & 6.99 & 1.89 & 2.17 \\
\hline 9.00 to 14.99 & 23 & 11.38 & 6.00 & 3.29 & 23 & 11.77 & 5.74 & 2.78 \\
\hline 15.00 to 20.99 & 26 & 18.27 & 12.42 & 3.11 & 27 & 17.95 & 13.11 & 3.19 \\
\hline 21.00 to 26.99 & 19 & 24.01 & 16.00 & 1.86 & 12 & 23.27 & 16.33 & 2.10 \\
\hline \multirow[t]{2}{*}{27.00 to 32.99} & 6 & 30.06 & 18.33 & 1.83 & 11 & 29.60 & 19.46 & 1.04 \\
\hline & \multicolumn{4}{|c|}{ Black Boys } & \multicolumn{4}{|c|}{ Black Girls } \\
\hline 3.00 to 8.99 & 17 & 6.47 & 0.59 & 0.94 & 30 & 6.43 & 0.70 & 1.09 \\
\hline 9.00 to 14.99 & 26 & 11.69 & 6.08 & 3.15 & 25 & 11.82 & 5.24 & 3.17 \\
\hline 15.00 to 20.99 & 12 & 19.00 & 12.00 & 3.81 & 18 & 17.84 & 13.44 & 4.12 \\
\hline 21.00 to 26.99 & 9 & 23.65 & 16.56 & 2.40 & 11 & 24.68 & 17.64 & 1.96 \\
\hline 27.00 to 32.99 & 12 & 30.43 & 20.00 & 0.00 & 7 & 29.10 & 19.14 & 1.57 \\
\hline
\end{tabular}

- SD, standard deviation.

present by age (Table 1) are shown graphically in the illustration. Boys of both races were ahead of girls of both races for the total number of deciduous teeth present in the earliest age groupings. This reflects male advancement for deciduous central and lateral incisor eruption. By the time of first molar emergence, however, ages 14 to 16 months, girls in both races became advanced in relation to boys and remained so to age 28 months, the age by which deciduous tooth emergence is usually completed in most children.

For the early stages of tooth emergence, 6 to 15 months, a greater number of girls in both races were below the boys' median trend line than were above. With race groups combined, the difference was significant $\left(x^{2}=4.08, d f=1\right)$. For the later stages of dental development (canine and molar emergence), girls were advanced significantly $\left(\chi^{2}=7.45\right)$.

The illustration also shows that white chil. dren of both sexes were ahead of black chil dren in the early stages of deciduous tooth emergence. However, by age 15 months, black girls surpassed white girls and by age 22 months, black boys surpassed white boys for the total number of teeth present.

\section{Discussion}

For both black and white children in this study, girls were behind boys during the period of incisor emergence, but were advanced through the period of first molar, canine, and second molar emergence.

Many investigators ${ }^{1-4,10}$ conclude that no sex differences in deciduous tooth emergence exist. A review of the literature, however, will make it apparent that boys tend to be

TABLE 2

Proportion of Girls Above and Below Race-Specific Boys' Trend Line for Median Number of Deciduous Teeth Present by Age

\begin{tabular}{|c|c|c|c|c|c|c|c|}
\hline \multirow[b]{2}{*}{ Tooth Eruption } & \multirow[b]{2}{*}{ Group } & \multicolumn{4}{|c|}{ Boys' Trend Line } & \multirow[b]{2}{*}{ Total } & \multirow[b]{2}{*}{$x^{2}$} \\
\hline & & Below & $\%$ & Above & $\%$ & & \\
\hline \multirow{3}{*}{$\begin{array}{l}\text { Early stages } \\
\quad(6 \text { to } 15 \text { months) }\end{array}$} & White girls & 31 & 57.4 & 23 & 42.6 & 54 & 1.19 \\
\hline & Black girls & 28 & 63.6 & 16 & 36.4 & 44 & 3.27 \\
\hline & Combined & 59 & 60.2 & 39 & 39.8 & 98 & $4.08^{*}$ \\
\hline Later stages & White girls & 14 & 33.3 & 28 & 66.7 & 42 & $4.67 *$ \\
\hline (more than & Black girls & 10 & 34.5 & 19 & 65.5 & 29 & 2.79 \\
\hline 15 months) & Combined & 24 & 33.8 & 47 & 66.2 & 71 & $7.45+$ \\
\hline
\end{tabular}

$* P<0.05$.

$+P<0.01$ 

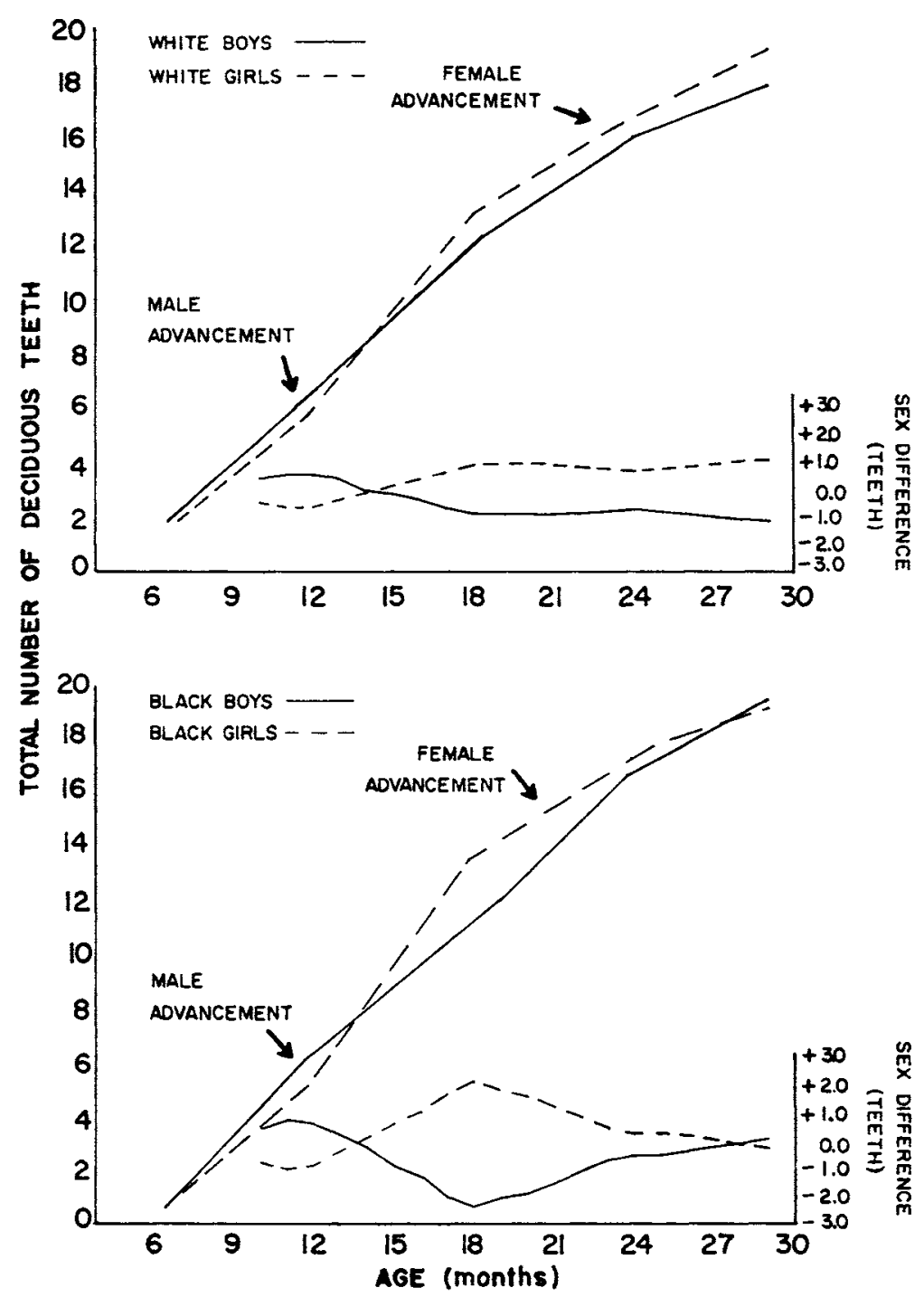

Mean total number of deciduous teeth erupted in white and black boys and girls by half-year age intervals.

slightly advanced in the early stages, and more irregularities occur in the later stages. The findings in this study for the boys' advancement in the early stages of dental development are similar to those observed in the literature. Significant advancement by girls in the later stages of deciduous tooth emergence, however, has not been reported previously. Since Burdi, Garn, and Miller, ${ }^{11}$ have reported male advancement in first trimester human embryos, the sex advancements in deciduous tooth emergence between boys and girls in this group of children suggest that girls, who are retarded in relation to boys during intrauterine dental development, remain so through the time of eruption of the lateral incisors, age 12 to 14 months. Girls then become advanced in dental development and remain advanced through the completion of deciduous dental emergence as well as deciduous tooth exfoliation ${ }^{12}$ and permanent tooth eruption. ${ }^{13,14}$

\section{Conclusions}

A study of deciduous tooth emergence in 376 white and black children of the lower 
socioeconomic level in southeastern Michigan indicated that boys of both races began deciduous tooth emergence at earlier ages than girls. Girls surpassed boys in tooth emergence by age 15 months and remained advanced through completion of the deciduous dentition; and the observed sex differences in the early and later stages of deciduous tooth emergence were significant statistically.

The author thanks S. M. Garn and A. L. Russell for their suggestions during the writing of this paper.

\section{References}

1. BoAs, F.: The Eruption of Deciduous Teeth Among Hebrew Infants, $J$ Dent Res 7:245253, 1927.

2. Falkner, F.: Deciduous Tooth Eruption, Arch Dis Child 32: 386-391, 1957.

3. Friedlaender, J.S., and Bailit, H.L.: Eruption Times of the Deciduous and Permanent Teeth of Natives on Bougainville Island, Territory of New Guinea: A Study of Racial Variation, Hum Biol 41: 51-65, 1969.

4. SANDLER, H.C.: The Eruption of Deciduous Teeth, J Pediatr 25: 140-147, 1944.

5. Meredith, H.V.: Order and Age of Eruption for the Deciduous Dentition, J Dent Res 25: 43-66, 1946.

6. Robinow, M.; Richards, J.W.; and ANderson, M.: The Eruption of Deciduous Teeth, Growth 42: 127-133, 1942.

7. Doering, C.R., and Allen, M.F.: Data on
Eruption and Caries of the Deciduous Teeth, Child Dev 13: 113-129, 1942.

8. Ferguson, A.; Scott, R.B.; and Baxwin, H.: Growth and Development of Negro Infants: VIII. Comparison of the Deciduous Dentition in Negro and White Infants, $J$ Pediatr 50: 327-331, 1957.

9. Lysell, L.; Magnusson, B.; and Thilander, B.: Time and Order of Eruption of the Primary Teeth, Odontol Revy 13:217-234, 1962.

10. MCGregor, I.A.; Thompson, A.M.; and Billewicz, W.Z.: The Development of Primary Teeth in Children from a Group of Gambian Villages, and Critical Examination of Its Use for Estimating Age, $\mathrm{Br} J$ Nutr 22: $307-314,1968$.

11. BURDI, A.R.; Garn, S.M.; and Miller, R.L.: Developmental Advancement of the Male Dentition in the First Trimester, $J$ Dent Res 49: $889,1970$.

12. Miller, J.; Hobson, P.; and Gaskell, J.J.; A Serial Study of the Chronology of Exfoliation of Deciduous Teeth and Eruption of Permanent Teeth, Arch Oral Biol 10: 805$818,1965$.

13. Steggerda, M., and Hill, J.J.: Eruption Time of Teeth Among Whites, Negroes and Indians, $A m$ J Orthod 28: 261-270, 1942.

14. Sutow, W.W.; Terasaki, T.; and OhWada, K.: Comparison of Skeletal Maturation with Dental Status in Japanese Children, Pediat. rics 14: 327-333, 1954. 